\title{
PEMETAAN KUALITAS UDARA KOTA SURAKARTA
}

\section{Mapping of Air Quality in Surakarta Municipality}

\author{
Oleh : \\ Drs. Ibnu Kadyarsi \\ Jurusan Kartografi dan Penginderaan Jauh \\ Fakultas Geografi UGM, Bulaksumur Yogyakarta \\ Telpon (0274).649.2334; Faksimile (0274) 589595
}

\begin{abstract}

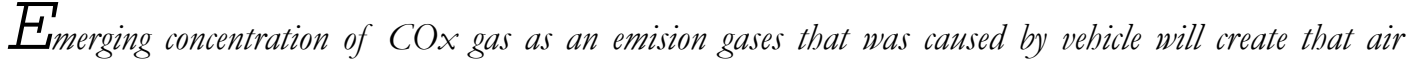
quality degradation in urban area. Air quality mapping was needed as a based map to solved on air quality problem in urban area. The aim of this research are mapping of air quality in Surakarta Municipality and to select the cartographic symbols which optimum to represent of air quality data especially Cox for more readable and analysis. Data collecting based on field survey in some observation point that derived purposively on several roads and dense traffict. Field data plotting on the map are used in some symbols such as pie-graph, bar-graph, and text. The mentioned symbols are usual in cartography to represent of point symbol. The result of this research is distribution map of COx concentration in Surakarta Municipality. The road which has high COx concentration are cross jucntion in downtown (west side of Pasar Klewer), cross junction of Yos Sudarso street, Slamet Riyadi Street, and cross junction of Hay Lay (Wates). The used of pie-graph and bar-graph symbols produce more interesting map visually, but unfortunately the symbols cover up the information in their based map. The used of text symbol is more easy to bandle for lay out, so the background object in based map is uncovere, but visually the map is not interesting.
\end{abstract}

Keywords: cartography symbul, mapping, air quality

\section{PENDAHULUAN}

Kota Surakarta adalah salah satu wilayah perkotaan di Provinsi Jawa Tengah yang saat ini merupakan wilayah yang sedang berkembang, baik dalam bidang industri, jasa, permukiman, pendidikan, perdagangan maupun transportasi. Seiring dengan perkembangan wilayah perkotaan tersebut maka terjadi alih fungsi lahan dari lahan pertanian yang tidak terbangun menjadi daerah terbangun (built up area). Alih fungsi ini akan meningkatkan kepadatan penduduk maupun kepadatan permukiman. Hal ini akan menyebabkan lingkungan semakin tidak dapat mendukung kehidupan secara harmonis (Haggett, 1983). Perluasan lahan terbangun beserta aktivitas penduduknya akan memicu permasalahan penurunan kualitas lingkungan. Salah satu permasalahan lingkungan yang sering terjadi di wilayah perkotaan akibat padatnya penduduk dengan sarana dan prasarana transportasinya menjadi sumber pemicu terjadinya pencemaran udara. Bila masalah pencemaran udara ini tidak segera ditanggulangi, maka akan menimbulkan masalah baru yang lebih kompleks seperti masalah kesehatan masyarakat dan wabah penyakit yang lain. 
Masalah penanggulangan pencemaran udara telah menjadi salah satu butir dalam Agenda 21. Program ini dilakukan dalam rangka mewujudkan blue sky city dan millenium city, dengan jalan pengelolaan lingkungan secara terpadu antar berbagai kepentingan baik oleh pemerintah maupun masyarakat (KLH, 2000 dalam Anonim, 2003). Untuk mewujudkan cita-cita tersebut maka harus dilakukan identifikasi permasalahan lingkungan secara spesifik dan rinci, sehingga penanganan yang dilakukan selanjutnya dapat berdaya guna dan berhasil guna. Salah satu kegiatan awal yang merupakan dasar bagi kegiatan pengelolaan lingkungan secara terpadu adalah pendataan dan pemetaan. Fenomena penurunan kualitas udara di wilayah Kota Surakarta merupakan salah satu kasus yang menarik untuk dipetakan. Hal ini terkait dengan meningkatnya jumlah kendaraan bermotor di wilayah ini. Dalam melakukan pemetaan, sering terjadi kendala yakni penggunaan dan penempatan simbul kartografi yang kurang menarik dan tidak mudah dimengerti, sehingga cukup mengganggu dalam membaca dan menganalisis informasi yang terkandung dalam peta. Berdasarkan uraian di atas, maka dalam penelitian ini ada dua tujuan yaitu: a) Mengkaji kondisi kualitas udara, khususnya kadar COx akibat meningkatnya perkembangan wilayah perkotaan di Kota Surakarta, b) Memetakan kualitas udara Kota Surakarta dengan menggunakan simbul kartografis yang optimum.

\section{TINJAUAN PUSTAKA}

\section{Pencemaran Udara}

Udara merupakan campuran beberapa macam gas yang berada di sekeliling bumi yang berfungsi sangat penting bagi seluruh kehidupan di dunia ini. Adanya pencemaran udara akan berakibat buruk bagi kehidupan. Sunu (2001, dalam Dewi 2004) menyatakan bahwa pencemaran udara ialah adanya bahan atau zat asing yang terdapat di udara dalam jumlah yang dapat menyebabkan perubahan komposisi atmosfer dari keadaan normal.

Pencemaran udara di daerah perkotaan cenderung semakin hari meningkat terutama daerah dengan kepadatan lalulintas yang cukup tinggi serta di lokasi industri. Tingginya konsumsi penggunaan bakar yang berasal dari minyak, maka potensi pencemaran udara juga semakin tinggi karena udara akan tercemar oleh gasgas buangan hasil pembakaran (Sunu, 2001, dalam Dewi, 2004).

Faktor yang mempengaruhi terjadinya pencemaran udara dapat disebabkan oleh berbagai macam hal, terutama bersumber dari aktivitas yang dilakukan oleh manusia. Bintarto (1983) menyatakan bahwa udara dicemarkan oleh :

- Kendaraan bermotor yang banyak memadati jalanan kota.

- Emisi atau kotoran melalui asap pabrik yang sudah banyak terdapat di kota dan sekitarnya.

- Kepadatan penduduk dan pembakaran sampah.

- Pembukaan daerah melalui tebang dan bakar yang mengakibatkan udara dipenuhi oleh carbon monoxide, nitrogen oxide, dan sulfur oxide.

Sunu (2001, dalam Dewi 2004) menjelaskan bahwa pada umumnya pencemaran udara disebabkan oleh kegiatan manusia yang tidak mengindahkan dampak lingkungan dan faktor alam. Penyebab pencemaran udara oleh kegiatan manusia seperti: debu/partikel 
dari kegiatan industri, penggunaan zat-zat kimia yang disemprotkan ke udara, dan gas buang hasil pembakaran bahan bakar fosil. Penyebab pencemaran udara oleh faktor alam, misalnya: debu akibat letusan gunung api, proses pembusukan sampah organik, dan debu yang berterbangan akibat tiupan angin.

Fardiaz (1992) menjelaskan bahwa polutan udara primer adalah polutan yang mencakup $90 \%$ dari jumlah polutan udara seluruhnya, dapat dibedakan menjadi lima kelompok, yaitu: 1) Karbon monokside (CO), 2) Nitrogen okside (NOx), 3) Hidrokarbon (HC), 4) Sulfur diokside (SOx) dan 5) Partikel. Pengaruh Karbon monoksida (CO). Pengaruh beracun CO terhadap tubuh terutama disebabkan oleh reaksi antara $\mathrm{CO}$ dengan hemoglobin $(\mathrm{Hb})$ di dalam darah. Hemoglobin di dalam darah secara normal berfungsi dalam sistem transpor untuk membawa oksigen dalam bentuk oksihemoglobin $\left(\mathrm{O}_{2} \mathrm{Hb}\right)$ dari paruparu ke sel tubuh, dan membawa $\mathrm{CO}_{2}$ dalam bentuk $\mathrm{CO}_{2} \mathrm{Hb}$ dari sel-sel tubuh ke paru-paru. Dengan adanya CO, hemoglobin dapat membentuk karboksi-hemoglobin. Jika reaksi demikian terjadi, maka kemampuan darah untuk mengangkut oksigen menjadi berkurang.

\section{Kartografi}

Peta sebagai sumber informasi keruangan (spasial) adalah amat penting dalam setiap kegiatan perencanaan, pelaksanaan, pemantauan pembangunan, dan pemerintahan. Ini berarti peta memiliki peran strategis dalam perumusan kebijakan pembangunan nasional. Dengan peta berbagai aktivitas pembangunan kewilayahan dapat dipadukan, dievaluasi, dan ditata ulang. Dengan peta pula segala informasi sumberdaya alam dan potensi wilayah dapat dipadukan untuk mendukung proses perencanaan yang matang dan bijaksana.

Peta merupakan gambaran unsurunsur atau kenampakan abstrak, yang dipilih dari permukaan bumi, atau yang ada kaitannya dengan permukaan bumi atau benda benda angkasa, dan umumnya digambarkan pada suatu bidang datar dan diperkecil/diskalakan (Robinson, et al., 1995). Peta dapat diklasifikasikan menjadi 3, yaitu: (a) peta topografi, menyajikan kenampakan fisik dan artificial (kultural dan hasil budaya manusia) di permukaan bumi; (b) charts, peta-peta untuk kepentingan navigasi, seperti peta jalur penerbangan, peta arah angin, peta jalan darat; dan (c) peta tematik, peta yang mencerminkan hal-hal khusus.

Dalam penyusunan peta tematik diperlukan peta dasar yang merupakan kerangka untuk penempatan unsur-unsur, atau pun obyek yang dipetakan (Borden, 1999). Peta dasar ini memuat berbagai macam unsur geografi (grid, pola aliran dan relief), unsur komunikasi (jalan, jalan kereta api, jalur pelayaran), unit administrasi, nama nama geografi. Unsur ini tidak secara bersama dapat termuat dalam satu peta dasar untuk pemetaan data tertentu, tetapi unsur yang terkait dengan tema saja yang digambarkan. Sebagai contoh, elemen topografi alami seperti pola aliran, garis kontur lebih erat hubungannya dengan tema peta geologi. Untuk peta peta yang bertema sosial ekonomi, misalnya: industri, pendidikan, pertanian lebih erat hubungannya dengan kenampakan buatan manusia, sehingga unsur unsur ini dimasukkan dalam peta dasar. Dengan demikian peta dasar yang baik untuk suatu tema tertentu belum tentu sesuai untuk tema yang lain. Peta yang 
baik, dari sisi efisiensi seharusnya dapat memuat sebanyak-banyaknya informasi tanpa harus menambah kompleksitas peta itu sendiri (Robinson et al., 1995). Peta dasar dapat diturunkan dari peta topografi, peta dunia, peta navigasi udara dan peta dunia lain dengan berbagai variasi skala. Dokumen lain yang dapat dipakai sebagai peta dasar adalah foto udara dan peta foto, bila tidak ada peta lain yang tersedia.

Peta merupakan sumber informasi. Informasi informasi ini diwujudkan dalam bentuk simbul. Untuk dapat mengungkap kembali informasi, pengguna peta perlu mengetahui bahasa peta yang dipergunakan oleh pembuatnya termasuk di dalamnya adalah simbul. Simbul dalam peta memegang peranan yang sangat penting. Dari simbul isi peta dapat diketahui. Bahkan dalam peta tematik simbul-simbul itu merupakan informasi utama untuk menunjukkan tema daripada peta (Bos dan Waag, 1968).

Untuk mendesain suatu simbul tidaklah mudah. Hal ini dapat dipahami karena ada dua hal yang pertu diperhatikan yaitu pembuat dan pengguna peta (Blok dan Mank, 1987). Dari sisi pembuat akan berusaha membuat simbul yang sederhana, mudah digambar, tetapi cukup teliti. Sedangkan bagi pengguna simbul itu harus jelas, mudah dibaca dan diinterpretasi, kontras antara elemen yang satu dengan yang lain, dan harus menarik. Unsur yang mempengaruhi dalam pembuatan simbul adalah data, persepsi kesan, dan variabel visual (Slocum, et al., 2005).

Sebelum memilih simbul sebelumnya perlu mengetahui tertebih dahulu mengenai data maupun informasi yang akan dicerminkan dalam peta mengenai sifat maupun ukuran. Dalam hal ini ada 4 ukuran data yang perlu diketahui yaitu: nominal, ordinal, interval dan rasio. Ukuran nominal, yaitu suatu unsur yang tidak mempunyai tingkatan. Unsur ini biasanya dikenal dengan nama, dan sifatnya kualitatif, misal: masjid, sekolah, pabrik dan sebagainya. Ukuran ordinal yaitu ukuran unsur dengan aturan tertentu yang mempunyai tingkatan, suatu unsur mempunyai derajad tebih tinggi dari yang lain atau sebaliknya. Ukuran interval dan rasio, merupakan ukuran dari suatu unsur yang tidak hanya dengan aturan tertentu tetapi juga dibagi atas kelas kelas tertentu dengan nilai yang sebenarnya. Pada ukuran nominal ini bersifat kualitatif sedang pada interval dan rasio bersifat kuantitatif karena sudah ada hubungannya dengan jumlah. Ukuran data ini perlu diperhatikan dalam proses desain simbul. Sebab simbul yang didesain telah mempertimbangkan faktor ini dan dapat tercermin dalam satuan simbul.

Persepsi adalah kesan yang timbul apabila pengguna mengamati suatu peta. Ada empat tingkat persepsi yang dapat dikenali, yaitu (Bos, 1975): a) Persepsi asosiatif, semua simbul yang ada pada peta mempunyai kesan sama tingkatannya, tidak ada satu simbul yang kelihatan lebih tinggi tingkatannya terhadap yang lain; b) Persepsi selektif, semua simbul terasa berbeda tetapi membentuk kelompok-kelompok. Mata dapat mengenal dengan sendirinya dari kelompok-kelompok ini. Diantara kelompok ini tidak ada perbedaan tingkat maupun kepentingan; c) Persepsi bertingkat, secara spontan mata dapat melihat semua simbul dalam suatu tingkatan; d) Persepsi kuantitatif, simbul simbul menampakkan jumlah secara porposional. Mata dapat dengan sendirinya mengenal dalam segi jumlah. 
Simbul merupakan infomasi utama, dan digambar dengan jelas. Bentuk simbul dapat berupa titik, garis dan bidang yang dapat digambar dengan wujud abstrak, setengah abstrak atau yang sesuai dengan kenyataan. Simbul fotografik yaitu simbul yang didapat dari proses fotografi dan bentuknya sesuai dengan keadaannya. Simbul yang didapat dari gambaran dengan tangan dan bentuknya menyerupai kenyataannya datanya disebut simbul piktorial. Simbul geometrik adalah simbul simbul yang abstrak, bentuknya sama sekali berbeda dengan kenyataannya. Tetapi justru simbul ini yang banyak dipakai karena sifatnya yang fleksibel, dan dapat dipakai untuk menunjukkan informasi yang cukup banyak (Robinson et al., 1995).

Dalam mendesain simbul pembuat peta perlu mempertimbangkan kepentingan penggunaannya. Paling tidak simbul yang dipakai tidak membingungkan dan mudah untuk dapat diinterpretasi. Ini sesuai dengan fungsi simbul yaitu sebagai suatu kode/tanda. Jangan sampai terjadi tanda ini tidak dapat dimengerti oleh pemakai. Elemen penting yang dapat memudahkan dalam pembacaan adalah ukuran simbul. Dapat disebutkan bahwa betapapun baiknya simbul yang dibuat, apabila ukurannya terlampau kecil untuk dapat dilihat, maka simbul tersebut tidak akan mempunyai arti.

Selain ukuran, kekontrasan dari simbul juga merupakan faktor pembantu dalam pembacaan. Perbedaan yang jelas antara elemen-elemen dalam simbul perlu diperhatikan. Kekontrasan ini dapat dicapai dengan variasi karakteristik dari garis garis, bentuk, pola maupun nilai. Untuk memperoleh persepsi yang jelas dalam pemilihan simbul, variabel visual dari sim- bul dapat membantu. Ada tujuh variabel visual simbul yaitu posisi, bentuk (form), ukuran (size), arah (orientation), nilai (va-lue), kepadatan (density), dan warna (colour).

Setiap data didesain sebaik mungkin agar informasi yang dapat diperoleh dari peta betul betul dapat memenuhi kebutuhan pengguna peta. Oleh karena itu segala informasi yang berkaitan dengan kebutuhan pembaca peta, terutama dalam hal kemudahannya untuk dibaca dan diinterpretasi, sangat diperlukan. Pada umumnya informasi tersebut pada lembar peta sebagai informasi peta, di samping muka petanya sendiri (tema dan daerah yang digambarkan pada daerah tertentu), membentuk suatu susunan atau tata letak peta yang disebut juga sebagai komposisi peta (Bos, 1975).

Penentuan tata letak peta atau komposisi peta harus mempertimbangkan cara cara yang dapat menyentuh perasaan tertarik (sensible) dan juga unsur keindahan perlu dipertimbangkan. Tata letak yang betul akan menjadikan penampilan peta secara keseluruhan menjadi lebih menarik. Salah satu faktor utama yang diperhatikan adalah adanya keseimbangan (balance) dalam tata letak informasi tepi. Ukuran huruf (text), tipe huruf (style), mempunyai peranan dalam komposisi tata letak informasi tepi ini, oleh karena itu besar-kecilnya huruf sangat perlu dipertimbangkan secara tepat pula. Komposisi peta pada peta tematik harus mempertimbangkan keseimbangan tata letak, di samping keserasian dalam hal ukuran dan tipe huruf. Informasi tepi paling tidak harus mencakup: judul, daerah yang dicakup, skala peta, legenda, keterangan orientasi utara, grid lintang bujur, indeks/petunjuk letak peta. 
Tabel 1. Prinsip Penulisan Huruf untuk Nama-Nama Geografi

\begin{tabular}{|l|l|l|l|}
\hline \multicolumn{1}{|c|}{ Huruf besar tegak } & \multicolumn{1}{c|}{$\begin{array}{c}\text { Huruf besar } \\
\text { miring/ italic }\end{array}$} & $\begin{array}{c}\text { Tegak huruf } \\
\text { kecil }\end{array}$ & $\begin{array}{c}\text { Miring italic } \\
\text { huruf kecil }\end{array}$ \\
\hline $\begin{array}{l}\text { Nama negara, provin- } \\
\text { si, pulau besar, kota } \\
\text { besar }\end{array}$ & $\begin{array}{l}\text { Lautan, laut, } \\
\text { sungai besar }\end{array}$ & Kota, desa, hutan & $\begin{array}{l}\text { Sungai, bentuk } \\
\text { pantai, pulau } \\
\text { kecil }\end{array}$ \\
\hline
\end{tabular}

Sumber: Erwin, 1948

Suatu hal yang tidak dapat dilupakan dalam peta adalah nama-nama geografis. Nama-nama geografis ini perlu dicantumkan dalam peta karena nama ini dipakai sebagai identifikasi suatu perujudan, walaupun sebetulnya nama sendiri bukan bagian dari muka bumi. Prinsip penulisan huruf untuk nama-nama geografi menurut Raisz Erwin (1948) adalah sebagai berikut (Tabel 1): a) Wilayah administrasi dan nama tempat, biasanya berwarna hitam, tetapi dapat pula berwarna lain, misalnya kelabu, apabila teks merupakan bagian dari peta dasar dimana informasi tematik dicetak di atasnya; b) Nama bentuk relief seperti pegunungan, bukit dengan huruf cetak miring (italic) hitam; c) Nama perairan/ perujudan air dengan huruf cetak miring (italic) warna biru.

\section{METODE PENELITIAN}

Data kualitas udara yang digunakan dalam penelitian ini berasal dari pengukuran lapangan. Titik pengamatan lapangan ditentukan secara purposif, yaitu pada ruas jalan yang volume lalu lintasnya padat. Data sekunder sebagai pendukung diperoleh dari survai institusional. Data kualitas udara hasil pengukuran lapangan diplotkan ke dalam peta dasar skala $1: 50.000$. Beberapa teknik penyajian data kualitas udara menggunakan simbul titik diujicobakan pada penelitian ini. Simbul yang lazim dipakai dalam kartografi untuk menyajikan informasi adalah pie-graph, bar-graph dan simbul teks.

Parameter kualitas udara perkotaan yang lazim dipetakan adalah COx, NOx, SOx dan kebisingan. Dalam penelitian ini hanya kadar COx saja yang dipetakan. Kadar NOx tidak dipetakan karena unsur ini hanya terdeteksi pada dua lokasi saja (lokasi No 1 dan No 3, Tabel 2). Kadar SOx juga tidak dipetakan karena hanya terdeteksi pada satu lokasi saja. Demikian halnya parameter kebisingan, variansi datanya terlalu sempit yakni berkisar antara 80-90 dB. Parameter kecepatan dan arah angin, suhu udara, dan kelembaban udara untuk suatu wilayah yang sempit (kawasan kota) jarang dipetakan pada skala semidetail.

Jumlah titik pengukuran dalam penelitian ini adalah 17 lokasi, yang dipilih secara purposif pada ruas jalan utama yang mempunyai kepadatan lalu-lintas tinggi. Pengukuran dilakukan pada 3 periode waktu, yaitu jam 6:00-7:00 (pagi), jam 12:00 13:00 (siang) dan jam 17:00-18:00 (sore). Dalam penelitian ini pembahasan ditekankan pada penggunaan simbul yang diterapkan pada peta dengan skala \pm 1:100.000, bukan dicetak pada peta kerja skala 1:50.000. Komposisi peta dan penulisan nama geografis tidak dibahas dalam penelitian ini. 
Analisis data dalam penelitian adalah analisis keruangan peta kualitas udara Kota Surakarta pada daerah sampel (17 titik pengamatan pada ruas jalan di Kota Surakarta). Analisis keruangan dilakukan dengan membandingkan antara data kualitas udara hasil pengamatan dengan standar yang diperkenankan atau Baku Mutu (BML)/ Nilai Ambang Batas (NAB) yang telah ditetapkan.

\section{HASIL DAN PEMBAHASAN}

Pengukuran kualitas udara dilakukan pada beberapa ruas jalan di Kota Surakarta. Pemilihan ruas jalan sebagai satuan pemetaaan ini, dengan asumsi volume lalu lintas relatif sama pada setiap ruas jalan yang diamati. Besar-kecilnya volume lalu lintas pada ruas jalan akan mempengaruhi kondisi kualitas udaranya.

Hasil pengukuran kualitas udara Kota Surakarta disajikan ke dalam 3 (tiga) macam peta tematik dengan simbul yang berbeda. Pemilihan simbul-simbul ini mempertimbangkan kemudahan dalam penggambaran, kemudahan untuk dibaca dan kemungkinan untuk dilakukan analisis. Simbul peta yang digunakan untuk menyajikan kualitas udara, meliputi: pie-graph, bar-graph, dan simbul teks.

Berdasarkan Tabel 2, dan Gambar 1, terlihat bahwa pemilihan simbul pie-graph sangat baik untuk menyajikan data kadar COx Kota Surakarta karena mudah dibuat, mudah dibandingkan antar data pada satu lokasi tetapi tidak dengan lokasi lainnya, dan memungkinkan dianalisis secara keruangan. Tetapi penggunaan simbul piegraph menggangu kenampakan pada peta dasarnya. Pada Gambar 2 digunakan simbul bar-graph untuk penyajian kadar COx. Pada penggunaan simbul bar-graph ini nampak bahwa penggunaan ruang tidak lentur, sehingga obyek pada peta dasar banyak yang tertutupi. Penempatan simbul pada peta tergantung posisi titik pengukuran, dan harus diletakkan sedekat mungkin dengan lokasi pengukuran. Penyajian peta dengan menggunakan simbul teks (Gambar 3), sangat mudah dibaca, tetapi penggunaan simbul ini relatif kurang menarik dari segi estetika.

Pada Tabel 2 terlihat bahwa kondisi pencemaran udara Kota Surakarta cukup mengkhawatirkan khususnya ruas jalan sebelah barat Pasar Klewer (lokasi nomor 2), perempatan Jl. Yos Sudarso (lokasi nomor 10), dan Wates (lokasi nomoe 11). Pola sebaran kadar COx pada daerah penelitian baik secara keruangan maupun waktu tidak menunjukkan pola tertentu. Nilai-nilai kadar COx yang terukur ada masing-masing lokasi hanya mencirikan kondisi setempat. Pada lokasi yang berdekatan misalnya lokasi nomor 5 dan 16, pengukuran COx pada siang hari menunjukkan kadar COx yang berbeda (masingmasing 6 ppm dan $12 \mathrm{ppm}$ ). Meskipun demikian, peta yang dihasilkan dalam penelitian ini cukup memberikan informasi yang memadai yang dapat digunakan untuk berbagai kepentingan. Sebagai contoh pada lokasi nomor 10 di daerah Kleco, menunjukkan kadar COx 35 ppm pada sore hari, yang merupakan nilai tertingi dalam penelitian ini, tetapi tidak demikian halnya pada pagi dan siang hari (masing-masing 2 ppm dan 5 ppm).

Dengan berdasar pada peta kualitas udara tersebut, maka dapat dilakukan langkah-langkah tertentu untuk mengurangi kadar pencemaran udara khususnya pada sore hari pada sekitar lokasi nomor 
10 (Kleco). Tingginya kadar COx di daerah Kleco pada sore hari, kemungkinan disebabkan oleh volume lalu lintas yang relatif tinggi dan ada kecenderungan daerah tersebut digunakan sebagai terminal bayangan bagi angkutan umum. Untuk mengurangi pencemaran, maka dapat dilakukan dengan penataan arus lalu lintas di daerah Kleco, yaitu dengan memberlakukan larangan untuk pemberhentian angkutan umum di daerah tersebut.

Secara umum kondisi kualitas udara Kota Surakarta, khususnya kadar COx, apabila dibandingkan dengan nilai Baku Mutu (BML), maka kadar kualitas udara Kota Surakarta masih di bawah BML. Kadar BML untuk COx daerah perkotaan adalah $26 \mathrm{ppm}$. Dari hasil pengamatan maka hanya ada satu lokasi yang kadar COx di atas BML. Tetapi beberapa lokasi kadar COx pada tingkat mengkawatirkan, karena nilainya mendejati BML. Pada lokasi yang nilai kadar COx mendekati nilai BML perlu ditindaklanjuti dengan kegiatan yang konkrit, misal dengan pengaturan atau manajemen lalu lintas.

Ruas jalan yang perlu pengaturan lalu lintas khusus, agar kualitas udara tetap terjaga, adalah ruas jalan sebelah barat Pasar Klewer, Jalan Yos Sudarso, dan Jalan Slamet Riyadi, dan jalan ke Purwosari. Ruas jalan tersebut di atas merupakan ruas jalan yang mendekati titik kritis. Pengaturan lalu lintas yang direkomendasikan adalah dengan meningkatkan pelayanan jalan berupa peningkatan kapasitas jalan. Peningkatan kapasitas jalan tidak harus dengan meningkatkan kualitas geometrik jalan, tetapi dapat dilakukan dengan pengaturan pemberhentian kendaraan atau pengaturan parkir pada badan jalan. Pada ruas jalan yang kualitas udaranya mulai menurun perlu dibatasi penggunaan badan jalan untuk parkir kendaraan.

Tabel 2. Kadar COx pada beberapa Lokasi di Kota Surakarta

\begin{tabular}{|c|l|c|c|c|}
\hline \multirow{2}{*}{ No } & \multirow{2}{*}{ Deskipsi lokasi pengukuran } & \multicolumn{3}{|c|}{ Kadar COx } \\
\cline { 3 - 5 } & & Pagi & Siang & Sore \\
\hline 1 & Pajang, batas kota tugu pensil & 5 & 22 & 7 \\
\hline 2 & Perempatan, tengah kota, barat Pasar Klewer & 23 & 13 & 17 \\
\hline 3 & Sangkrah, pinggir timur kota, tepi Bengawan Solo & 4 & 3 & 1 \\
\hline 4 & Joyotakan, batas kota, jembatan K. Premwulung & 6 & 2 & 4 \\
\hline 5 & Gladak, tengah kota bagian timur, selatan balai kota & 2 & 6 & 9 \\
\hline 6 & Taman Satwa Jurug, pinggir timur kota & 2 & 20 & 6 \\
\hline 7 & Perempatan depan SLTP 6, selatan Pasar Kliwon & 4 & 4 & 27 \\
\hline 8 & Gilingan, timur Terminal Tirtonadi & 4 & 1 & 3 \\
\hline 9 & Tugu Adipura, batas kota & 2 & 9 & 2 \\
\hline 10 & Kleco, batas kota & 2 & 5 & 35 \\
\hline 11 & Perempatan Jl. Yos Sudarso dan Jl. Slamet Riyadi & 10 & 10 & 14 \\
\hline 12 & Wates, trafic light depan Hay Lay & 10 & 16 & 12 \\
\hline 13 & Banyuanyar, pinggir Kali Pepe hulu & 5 & 4 & 12 \\
\hline 14 & Kadipiro, jembatan batas kota & 3 & 15 & 6 \\
\hline 15 & Jl. Gadjah Mada, depan Gedung Pers Nasional & 1 & 3 & 10 \\
\hline 16 & Serengan, utara Kali Premwulung & 4 & 12 & 6 \\
\hline 17 & Sondakan, perempatan ke Purwosari & 2 & 16 & 11 \\
\hline
\end{tabular}

Sumber : hasil pengukuran lapangan 


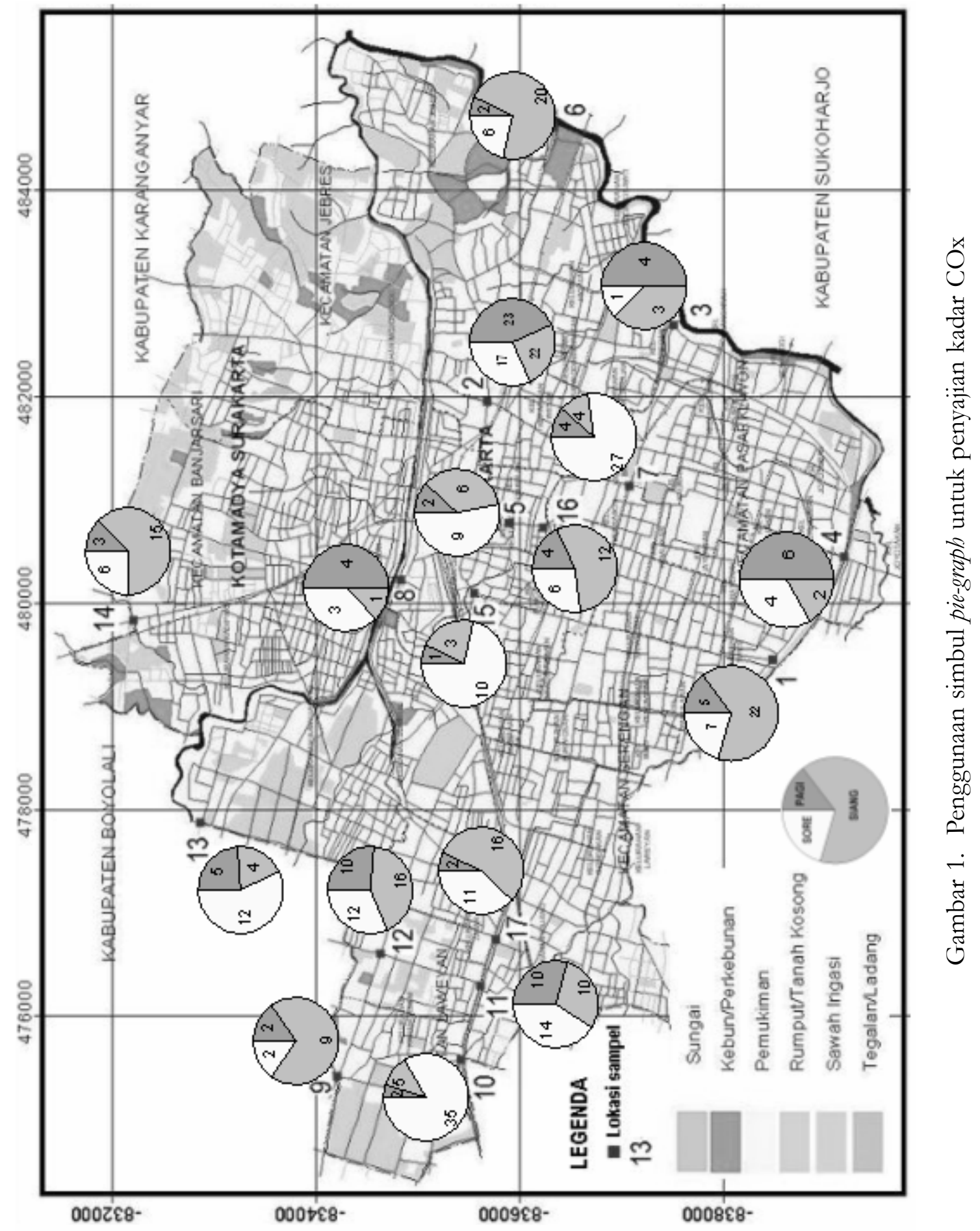




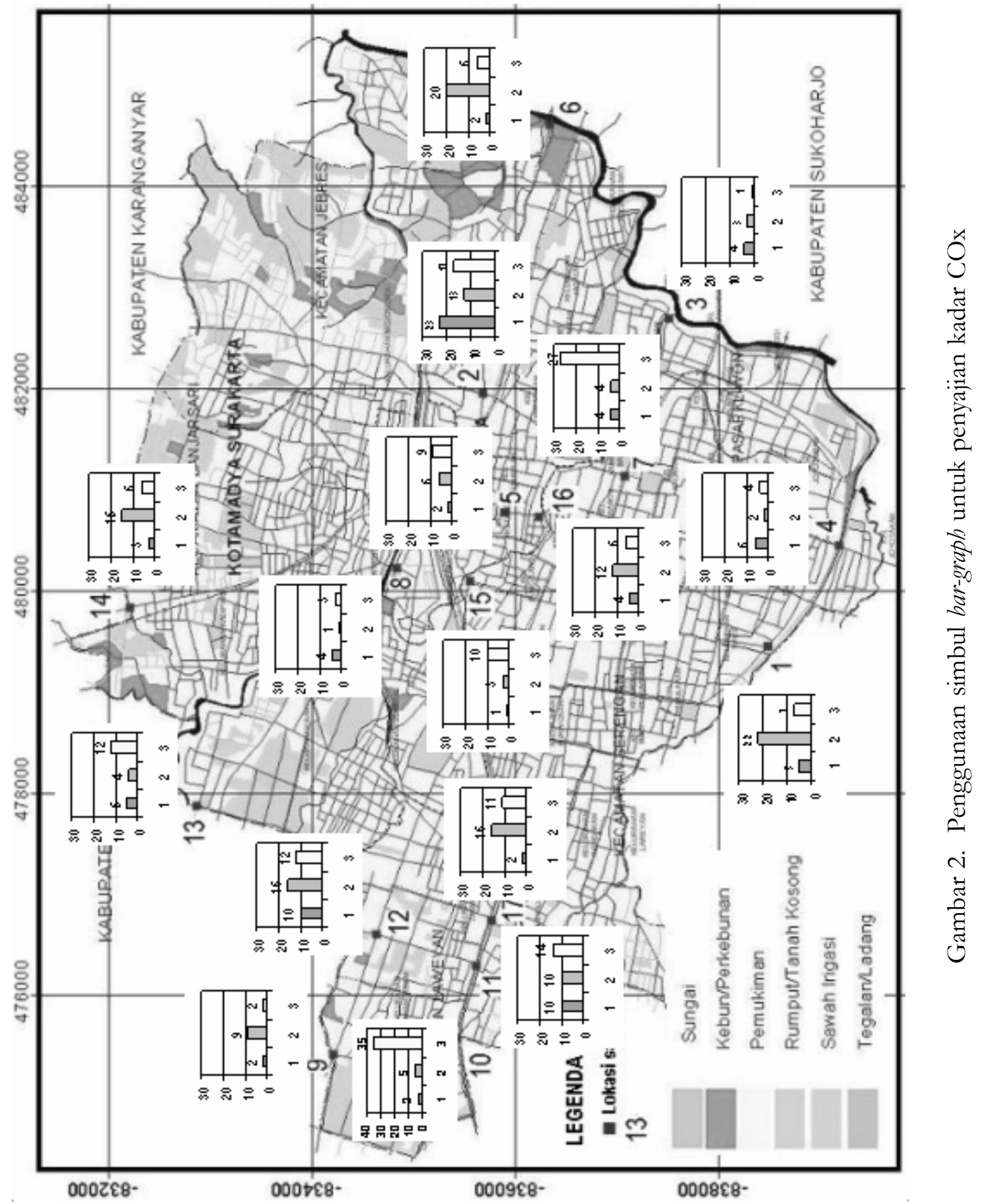




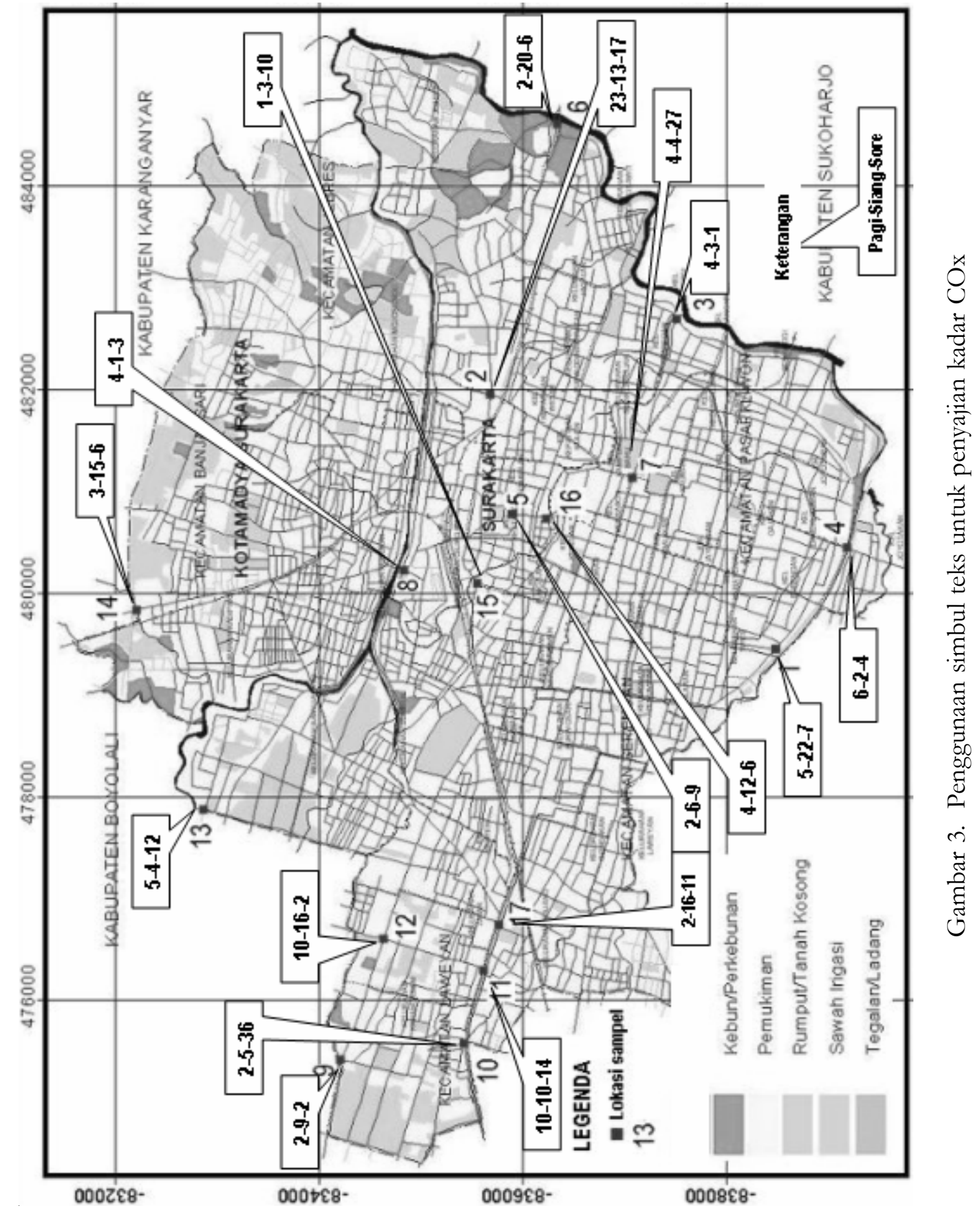




\section{KESIMPULAN}

Kualitas udara Kota Surakarta dapat disajikan dalam bentuk peta tematik kualitas udara. Tiga macam simbul digunakan dalam pemetaan ini, meliputi: piegraph, bar-graph, dan teks. Dari data yang dianalisis, perbedaan ulangan pagi, siang dan sore tidak menunjukkan suatu pola tertentu. Pemetaan kadar COx di Kota Surakarta ini dapat menunjukkan lokasilokasi ruas jalan dengan kualitas udara-nya, khususnya kadar COx.

Penggunaan simbul pie-graph dan bargraph sangat baik secara visual, tetapi obyek pada peta dasar tertutupi oleh simbul tersebut. Penyajian dengan simbul teks akan mengurangi adanya kehilangan informasi peta dasar, tetapi pengunaan simbul teks kurang menarik dari segi estetika.

Secara umum kualitas udara Kota Surakarta relatif masih baik, hanya beberapa ruas jalan kualitas udaranya pada tingkat mengkawatirkan. Ruas jalan yang kualitas udaranya mendekati nilai BML adalah Ruas jalan yang kadar COx tinggi sepanjang hari adalah Perempatan tengah kota (sebelah barat Pasar Klewer). Perempatan Jl. Yos Sudarso dan Jl. Slamet Riyadi, dan Wates (perempatan depan Hay Lay).

\section{UCAPAN TERIMA KASIH}

Sebagian data yang digunakan dalam penelitian ini diambil dari kegiatan Penelitian kerjasama antara Kantor Lingkungan Hidup Kota Surakarta dengan Lembaga Pengabdian Masyarakat UGM tahun 2003, untuk itu diucapkan terima kasih terutama kepada anggota Tim Peneliti. Penulis juga mengucapkan terima kasih kepada temanteman sejawat yang meluangkan waktunya memberi masukan dalam tulisan ini. Demikian pula kepada para editor diucapkan terima kasih.

\section{DAFTAR PUSTAKA}

Anonim. 2003. Pemetaan Kualitas Udara dan Kebisingan Kota Surakarta. Kerjasama antara Kementerian Lingkungan Hidup dengan Lembaga Pengabdian kepada Masyarakat Universitas Gadjah Mada, Yogyakarta

Bintarto, R. 1983. Interaksi Desa-Kota dan Permasalabannya, Ghalia Indonesia.

Blok, C.A. dan Mank, A.M., 1987. Production of the geomorphological map of Sri Lanka. ITC Journal 1987-1, hal. 18-22

Borden, D., 1999. Cartography: Thematic Map Design. WCB McGraw-Hill, New York.

Bos, E.S, 1975. Cartographic Principle in Thematic Mapping. ITC, Enschede.

Bos, E.S. and Van der Waag, A. 1968. Instruction for Drawing and Reproduction of Thematic Maps. ITC, Enschede.

Dewi, 2004. Aplikasi Teknik Penginderaan Jauh untuk Estimasi Potensi Pencemaran Udara di Kawasan Malioboro. Fakultas Geografi UGM, Yogyakarta 
Erwin, R., 1948. General Cartography. Institute of Geographical Exploration, London , 1962. Principles of Cartography. Mc. Graw Hill Book Company, New York.

Haggett, P., 1983, Geography : A Modern Synthesis. Happer \& Row Publ., London.

Robinson, A.H., Morrison, J.L., Muehrcke, P.C., 1995. Elements of Cartography. John Wiley \& Sons, New York.

Slocum, T.A., McMaster, R.B., Kessler, F.C., Howard, H.H., 2005. Thematic Cartography and Geographic Visualization, Pearson Prentice Hall, New Jersey. 